\title{
Physicochemical properties of effluents from three food processing industries in Anambra State, Nigeria
}

\author{
Nwosu Udoka Lovelyn ${ }^{1}$, Ajiwe Vincent Ishmael Egbulezu ${ }^{2}$, Okoye Patrice-Anthony Chudi ${ }^{2}$ \\ ${ }^{1}$ Department of Food Technology, Federal Polytechnic Oko, Anambra State, Nigeria \\ ${ }^{2}$ Department of Pure and Industrial Chemistry, Nnamdi Azikiwe University, Awka, Nigeria
}

Email address:

udolove4sure@gmail.com (Nwosu U. L.), vaj_04@yahoo.com (Ajiwe V. I. E.), pacnau05@yahoo.com (O. Patrice-Anthony C.)

\section{To cite this article:}

Nwosu Udoka Lovelyn, Ajiwe Vincent Ishmael Egbulezu, Okoye Patrice-Anthony Chudi. Physicochemical Properties of Effluents from Three Food Processing Industries in Anambra State, Nigeria. American Journal of Applied Chemistry. Vol. 2, No. 5, 2014 , pp. 91-95. doi: 10.11648/j.ajac.20140205.15

\begin{abstract}
Effluent samples from three food processing industries in Anambra State, Nigeria were monitored for levels of physicochemical properties using standard analytical methods. The results obtained were compared with the Nigeria Federal Ministry of Environment (FMENV) effluent limit to ascertain the level of conformity of these industries with the standard. Results showed that the $\mathrm{pH}$ levels of the effluents were acidic in the rainy season and lower than the value set by the FMENV for industrial effluent limit. Hardness levels were higher in the rainy season than values obtained in the dry season and were higher than the set standard (except KP, dry season). Other physicochemical properties of the effluents were either within or below the allowable industrial effluent limit. Two sample paired t-test showed that $\mathrm{pH}$, TS, TDS, TSS and sulphate levels were highly significant $(\mathrm{p}<0.05)$ between rainy and dry season. Analysis of variance indicated that there were significant difference $(\mathrm{P}<0.05)$ in the mean levels of $\mathrm{pH}, \mathrm{TS}$, TDS and nitrate among the three samples but TSS was not significant.
\end{abstract}

Keywords: Effluents, Physicochemical Properties, Food Processing Industry, FMENV

\section{Introduction}

Industrial pollution has been and continues to be a major factor causing the degradation of the environment around us, affecting the land we live on, the water we use and the air we breathe. Many industrial activities are responsible for discharging waste into the environment, and these wastes contain many poisonous substances that will contaminate the soil. Industries, according to Alao et al., (2010) vary according to process technology, size, nature of products, characteristics, complexity of wastes discharged and the receiving environment. Due to the highly diversified nature of food processing industries, various food processing, handling and packaging operations create wastes of different quality and quantity which if not treated before discharge into the environment could lead to increased disposal problem and consequently severe pollution problem.

The careless disposal of industrial effluents and other wastes may contribute greatly to the poor quality of the water (Chindah et al., (2004), Emongor et al., (2005), Furtado et al., (1998), Ugochukwu, (2004). Again, a study by Fakayode, (2005), on the impact of industrial effluent on water quality of a river revealed that the chemical parameters studied were above the allowable limits and also tended to accumulate down stream. It is pertinent to note that most of the rivers, seas, streams and even open gutters/drainages in the developing countries are the end points of effluents discharged from these industries. This made Olayinka, (2004) assert that these industrial effluents, if not treated and properly controlled can also pollute ground water. Since people use untreated waters from these sources, the result is the continuous outbreaks of diseases such as cholera, bilharzias, diarrhea and others.

Pollution of the aquatic environment has been defined by $\mathrm{UNESCO} / \mathrm{WHO} / \mathrm{UNEP}$ as the introduction by man directly or indirectly of substances or energy into the marine environment which results in such deleterious effects as harm to the living resources, hazards to human health, hindrance of marine activities including fishing and impairment of quality for use of sea water. Basically, different industries discharge oils which is harmful to both plants and aquatic lives and gas which cause air pollution. Effluents generally have an adverse effect on water bodies such as lakes, rivers, oceans and ground water and this, according to Abel, (1996) is 
caused by human activities. Pollutants in water include a wide range of chemicals, pathogens and physical chemistry or sensory changes. Alterations of water's physical chemistry are often caused by changes in characteristics and operation condition (David, 2002).

Pharmaceutical industries discharge wastewater which can be hazardous, this is also the case with fertilizer industries. In the past, our grand parents lived in small communities where wastes resulting from human activities were dispersed over large expanse of land, resulting in little or no adverse effects on the environment. However, in recent years, the remarkable population growth, urbanization, oil boom and subsequent expansion of industries have increased the volume and strength of wastewater on land, water and air. Chloride is widely used to kill bacteria in municipal water, sewage treatment plants and to destroy various microorganisms found in plumbing lines in water works stations. Acids from industrial operations and acid mine drainages especially in coal and sulphide areas remain serious sources of surface and ground water pollution. Moreover, the run-off from fertilized fields carries some of the fertilizers along with the industrial effluents to rivers which provide nutrients that increase the growth of algae.

It is generally believed that human health and wellbeing is intimately connected to the well-being of the natural environment and all other life forms. The availability and purity of traditional foods and medicines are diminished as a result of industrial contamination and the disruption of wildlife habitat, thus, the key to effective environmental quality management is the ability to continuously monitor the concentration of various pollutants in the sample of interest. It was against this background that this research was initiated to assess the physicochemical parameters of the effluents from three food processing industries in Anambra State.

\section{Materials and Methods}

\subsection{Sample Collection}

Effluent samples were collected from three food processing industries (Resource Improvement and Manufacturing Company Nnewi, Kingsize Pharmaceutical Company, Ogidi and Obisco beverages Ogidi) in Anambra State, Nigeria. Samples were collected at one month interval starting from June- September (rainy season) and October January (Dry season). A total of eight sampling trips were made on each of the companies comprising four months rainy season and four months dry season for effective comparison.

Samples were collected at different sports along the discharge of the effluent, starting with the point of discharge $\left(\mathrm{P}_{1}\right)$ to 30 meters away from the point of discharge $\left(\mathrm{P}_{3}\right)$. The first sample was collected at the point of discharge of the effluent $\left(\mathrm{P}_{1}\right)$, then 15 meters away from the point of discharge $\left(\mathrm{P}_{2}\right)$ and finally, 30 meters away from the point of discharge $\left(\mathrm{P}_{3}\right)$, making a total of three sampling points per food industry per month. Samples were collected using a 2 - litre plastic container with a screw cap. The container was initially washed with detergent, rinsed with distilled water and at the point of collection, it was rinsed three times with the sample before collection.

\subsection{Physicochemical Analysis}

The $\mathrm{pH}$ of the wastewater samples was taken insitu using Hana micro processor $\mathrm{pH}$ meter standardized with $\mathrm{pH}$ buffer. Hardness, Total Solids (TS) and Total Dissolved Solids (TDS) were determined using a flame photometer. Nitrate and sulphate levels was carried out using a UV spectrophotometer (1608 Shimadzu model) as described by APHA, (1992).

\subsection{Reagents and Materials}

Some of the reagents used are $0.1 \mathrm{~m} \mathrm{HCl}$, methyl orange indicator, phenolphthalein indicator, 0.01M EDTA, 0.014M AgNO3 solution, potassium chromate indicator, Barium chloride crystals, standard $0.02 \mathrm{M}$ sodium chloride solution and evaporating dishes.

Materials used include portable $\mathrm{pH}$ meter (Hanna microprocessor), evaporating dishes, muffle furnace, analytical balance, drying oven, desiccator, conical flasks and millipore filter paper.

\subsection{Physical Parameters}

\subsection{1. $\mathrm{pH}$}

Procedure:

The $\mathrm{pH}$ of the effluents were measured using a portable $\mathrm{pH}$ meter at the sampling point. This was done by rinsing the electrode with the sample. (Effluents) prior to the determination. The meter was allowed stabilize before taking the readings.

\subsubsection{Total Solids (TS) \\ Procedure}

Clean dry evaporating dishes were ignited at $550 \mathrm{oC}$ for 1 hour in a muffle furnance. They were allowed to cool, weighed and stored in a desiccator, $100 \mathrm{ml}$ of each effluent sample was measured and transferred into each of the preweighed dishes. The samples were evaporated to dryness on a water bath, allowed to cool and weighed.

$$
\text { Total solids }(\mathrm{mg} / \mathrm{l})=\frac{\mathrm{Ws} \times 100^{6}}{\mathrm{Vi}}
$$

where Ws = weight in gramme of residue obtained.

$\mathrm{Vi}=$ volume of sample evaporated.

\subsubsection{Total Suspended Solids (TSS)}

\section{Procedure}

The Millipore filter paper was dried, weighed and filtered into a funnel. $100 \mathrm{ml}$ of the effluent sample was filtered through it. The filter paper was removed and dried in the oven at $105 \mathrm{oC}$ for 1 hour. It was later cooled in a desiccator and weighed. 


$$
\text { Total suspended solids }(\mathrm{mg} / \mathrm{l})=\frac{(\mathrm{A}-\mathrm{B}) \times 1000}{\operatorname{Vol} \text { of Sample }(\mathrm{ml})}
$$

where $\mathrm{A}$ = weight of filter paper + residue in $\mathrm{mg}$,

$\mathrm{B}=$ weight of filter paper in $\mathrm{mg}$.

\subsubsection{Total Dissolved Solids}

The total dissolved solids was easily obtained by simple calculation.

Total dissolved solids $=$ Total solid - Suspended solids.

\subsection{Chemical Parameters}

Chemical parameters monitored are: nitrate, hardness, sulphate.

\subsubsection{Total hardness Determination}

This was done using APHA, (1980) method of EDTA Titrimetric method.

Principle:

Ethylene diaminoacetic acid and its sodium salt (EDTA) form a chelated soluble complex when added to a solution of certain metal cation. If a small amount of a dye such as Eriochrome Black $\mathrm{T}$ is added to an aqueous solution containing Calcium and magnesium ions at $\mathrm{pH}$ of $10.0+0.1$, the solution becomes wine red.

If EDTA is added to a titrant, the calcium and magnesium will be complexed and the solution turns from wine red to blue, marking the end point of the titration.

Procedure:

$25 \mathrm{ml}$ of the sample was pipetted into the conical flask and two drops of Erichrome Black T solution was added.

$2 \mathrm{ml}$ of ammonia buffer was titrated with 0.01M EDTA solution. The colour changed from wine red to blue black when the end point was attained.

Calculation:

$$
\text { Total Hardness }(\mathrm{mg} / \mathrm{CaC} 03 / 1)=\frac{\mathrm{V} \times \mathrm{M} \times 2.5 \times 1000 \times 5}{\text { Vol. of sample used }}
$$

Where $\mathrm{V}=$ Vol. of EDTA used in titration

$\mathrm{M}=$ Equivalent weight of $\mathrm{Ca} 2+$

$\mathrm{S}=$ Strength of ETDA

$2.5=\frac{\text { Molecular mass of } \mathrm{CaCO}_{3}}{\text { Atomic mass of } \mathrm{Ca}^{2+}}$

\subsubsection{Sulphate Determination}

Principle

Sulphate ion is precipitated in a hydrochloric acid medium with Barium chloride so as to form Barium sulphate (BaS04) crystals of uniform size. Light absorbance of the BaS04 suspension is measured by a transmission photometer and the sulphate ion concentration is determined by comparison of the reading from a standard curve.

Procedure

Formation of Barium Sulphate turbidity: $100 \mathrm{ml}$ each of the standard solution were poured into conical flask. To each standard was added $5.00 \mathrm{ml}$ conditioning reagent with stirring for one minute. While still stirring, a spatula full of Barium chloride crystal was added.

Distilled water was used to standardize the spectrophotometer. This was powered into absorption cell of the spectrophotometer and after placing the cell at the compartment, the galvanometer was adjusted to zero absorbance. One of the cells was emptied and filled to the mark with treated standard solution, this was placed in the compartment and was allowed to stand for four minutes. The absorbance was read at $430 \mathrm{~nm}$ wavelength. $100 \mathrm{ml}$ of each sample in the twin cell was taken and treated the same way as the standard and the absorbance was also recorded.

Preparation of Calibration curve

The absorbance of the standard solution was plotted against their concentrations to obtain the calibration curve. This was used to obtain the concentration of sulphate in the samples.

$$
\mathrm{mgSO}_{4} / 1=\frac{\mathrm{mgSO}_{4-} \times 1000}{\mathrm{ml} \mathrm{samples}}
$$

\subsubsection{Determination of Nitrate}

\section{Procedure}

$100 \mathrm{ml}$ each of the standards were transferred to a set of $250 \mathrm{ml}$ beakers. To these standards were added $2 \mathrm{ml}$ of $30 \%$ $\mathrm{NaCl}$ solution, $20 \mathrm{ml}$ of concentrated sulphuric acid and swirled. $0.2 \mathrm{~g}$ of Brucine reagent was added to all the flasks which produced color development. $10 \mathrm{ml}$ each of the samples and a blank were titrated with the same reagents as the standard. The absorbance of the standards and the samples were read with spectrophotometer at $410 \mathrm{~nm}$.

The readings of the standard were plotted against their concentration to obtain the calibration curve. The total nitrate concentrations for the samples were calculated from the calibration curve by interpolation.

\subsection{Analysis of Data}

Means of triplicate readings $(\mathrm{mg} / \mathrm{l})$ obtained from this study were subjected to t-test and analysis of variance (ANOVA) using statistical package for social science (SPSS version 20) computer software to see if there was a significant difference in the mean levels of the physicochemical properties of the effluents between rainy and dry season and also to ascertain whether the mean concentrations of the physicochemical parameters of the effluents differed among the various effluent samples monitored. Significance was accepted at the $\mathrm{P}<0.05$ level.

\section{Result}

The results of the physicochemical properties of the effluents from the three food industries monitored in both rainy and dry seasons were presented in Table 1, while that of the pollution index was also shown in Table II. From Table I, it was observed that the $\mathrm{pH}$ and TSS of the effluents were lower in the rainy season than in the dry season. $\mathrm{pH}$ values 
(rainy season) were lower than the value recommended by FMENV, (1991) for industrial effluent, while in the dry season, it was only RIMCO effluent that gave low $\mathrm{pH}$ value confirming that these effluents are highly acidic and will be toxic to soil, water and aquatic lives where they are discharged. The Table also revealed that the TS, TDS, hardness and sulphate levels were higher in the rainy season than values obtained for these parameters in the dry season. Though the mean concentrations of TS, TDS and sulphate were below the limit allowed by FMENV, (1991) for industrial effluent, hardness levels (except KP, dry season) were higher than the Nigerian effluent limitation guideline (Table 1).

\section{Discussion}

Low $\mathrm{pH}$ values obtained from these effluents (Table 1) could be as a result of acid rain which mixed with the effluents leading to increased acidity of the effluents. This could increase the acidity of the receiving streams, a situation which according to Chukwu, (2008) will be deleterious to aquatic lives and even humans when such foods such as oyster, shrimps, fish and water snails from such streams are consumed. Statistical analysis showed that the $\mathrm{pH}$ values of the effluents differed significantly $(\mathrm{P}<0.05)$ between rainy and dry season. Again, TS levels were higher in the rainy season than in the dry season in the three effluents monitored. Total solids contribute to high turbidity of water bodies into which they are discharged. TS levels (rainy season) varied significantly $(\mathrm{P}<0.05)$ from that of the dry season. The mean TDS were also higher in the rainy season than the dry season, though lower than the allowable standard (FMENV, 1991). A low level of TDS implied that the sediments are of small size which, according to Chukwu, (2008) was more dangerous since they could easily hamper respiration of sea animals by blocking the respiratory pores. He further stated that high value of TDS might also lead to nutrient enrichment (eutrophication) of receiving water bodies. This called for proper sedimentation process if the quality of the wastewater was to be improved. TDS levels was highly significant $(\mathrm{P}<0.05)$ between rainy and dry season.

On the other hand, the mean values of TSS obtained from these effluents were higher in the dry season than rainy season, though lower than the Nigerian industrial effluent standard. Aloa et al., (2010) reported that the low value of TSS in the rainy season could be attributed to the permeation of the effluents as they travel along their pathways, filtering the solid material out. Water high in suspended solids might be aesthetically unsatisfactory for bathing and the effect of the presence of TSS is the turbidity due to silts and organic matter. Hardness levels from the effluent samples were relatively high in both seasons and were higher than the limit recommended by FMENV, (1991) for industrial effluent (except KP effluent, dry season). There was, however, no significant difference $(\mathrm{P}>0.05)$ in hardness levels of the effluents between rainy and dry season and also among the three effluents except that seen between KP and RIMCO (Pvalue 0.03 ).

The total mean levels of Nitrate and sulphate recorded in this work were below the values allowed by FMENV, (1991) for industrial effluent limit for the two parameters. Nevertheless, sulphate levels were significantly higher in the rainy season than the values obtained in the dry season (Table 1).

Pollution index of the physicochemical parameters was shown in Table II. It showed the relative pollution contributed by each parameter. Pollution index of more than one $(\mathrm{Pi}>1.000)$ showed that the average concentrations of the physicochemical parameters were above the allowable limits, while indices less than one $(\mathrm{Pi}<1.000)$ indicated no pollution from the said parameters. From the pollution index Table (Table II), it was observed that the physicochemical parameters of the effluents from the three industries monitored contributed little to the pollution profile of the effluents since index values were less than one ( $\mathrm{pi}<1.000$ ). Nevertheless, the continued discharge of these effluents into the environment might result in severe accumulation of these pollutants into toxic levels which might affect crop yield, aquatic ecosystem and even human health.

\section{Conclusion and Recommendation}

Generally, this work has shown that apart from $\mathrm{pH}$ and hardness levels, other physicochemical parameters monitored were either within or below the limit set by the Nigerian Federal Ministry of Environment for industrial effluent. Although the mean values of the parameters in some cases were lower than the allowable limits, the continued discharge of the effluents into the environment or receiving water bodies without proper treatment might lead to severe accumulation of these contaminants/pollutants which might in turn affect crop yield and human health.

Careless discharge of these effluents should be discouraged and if possible, there is need for industries to install a treatment plant for all the industrial wastes so that they are properly treated before being discharged into the environment. 
Table 1. Mean + S.E of the Physicochemical properties of the effluent samples in both rainy and dry season compared to the FMENV, (1991) standard.

\begin{tabular}{|c|c|c|c|c|c|c|c|}
\hline \multicolumn{4}{|l|}{ Rainy Season } & \multicolumn{4}{|l|}{ Dry Season } \\
\hline Parameters tested & KP & Obisco & RIMCO & KP & Obisco & ROMCO & FMENV (1991) \\
\hline $\mathrm{pH}$ & $5.508 \pm 0.414$ & $5.625 \pm 0.414$ & $2.908 \pm 0.414$ & $6.600 \pm 0.414$ & $6.017 \pm 0.414$ & $5.033 \pm 0.414$ & $6-9$ \\
\hline Total Solids (mg/l) & $1175.00 \pm 103.957$ & $\begin{array}{l}891.667 \pm 103.9 \\
57\end{array}$ & $533.333 \pm 103.957$ & $408.500 \pm 103.957$ & $487.500 \pm 103.957$ & $599.167 \pm 103.957$ & $2030(\mathrm{mg} / \mathrm{l})$ \\
\hline TDS (mg/l) & $\begin{array}{l}1174.654 \pm 103.91 \\
6\end{array}$ & $\begin{array}{l}891.283+103.9 \\
16\end{array}$ & $532.933 \pm 103.916$ & $407.767 \pm 103.916$ & $486.026 \pm 103.916$ & $558.600 \pm 103.916$ & $2000(\mathrm{mg} / \mathrm{l})$ \\
\hline TSS (mg/l) & $0.346 \pm 0.069$ & $0.383+0.069$ & $0.400 \pm 0.069$ & $0.567 \pm 0.069$ & $0.725 \pm 0.069$ & $0.567 \pm 0.069$ & $30 \mathrm{mg} / \mathrm{l}$ \\
\hline Hardness mg/l) & $260.000 \pm 118.956$ & $\begin{array}{l}455.143+134.8 \\
83\end{array}$ & $423.667 \pm 145.691$ & $87.333 \pm 103.019$ & $242.733 \pm 103.109$ & $410.833 \pm 103.019$ & $100(\mathrm{mg} / \mathrm{l})$ \\
\hline $\begin{array}{l}\text { Nitrate (mg/l) } \\
\text { Sulphate }\end{array}$ & $\begin{array}{l}1.004 \pm 0.353 \\
87.917+9.346\end{array}$ & $\begin{array}{l}4.166 \pm 0.353 \\
53.333+9.346\end{array}$ & $\begin{array}{l}1.333 \pm 0.353 \\
41.875+9.346\end{array}$ & $\begin{array}{l}2.050 \pm 0.535 \\
10.792+9.346\end{array}$ & $\begin{array}{l}2.135 \pm 0.353 \\
8.083+9.346\end{array}$ & $\begin{array}{l}0.683 \pm 0.353 \\
8.458+9.346\end{array}$ & $\begin{array}{l}500 \mathrm{mg} / \mathrm{l} \\
250 \mathrm{mg} / 1\end{array}$ \\
\hline
\end{tabular}

Table 2. Pollution index of the physicochemical properties of the effluents

\begin{tabular}{llllllll}
\hline Effluent from & pH & TS & TDS & TSS & Hardness & Nitrate & Sulphate \\
\hline KP & 6.054 & 791.666 & 791.210 & 161.330 & 1.527 & 49.354 & 49.354 \\
Obisco & 5.820 & 689.583 & 688.654 & 0.554 & 320.990 & 3.150 & 30.708 \\
RIMCO & 3.970 & 546.250 & 545.766 & 0.483 & 415.110 & 1.008 & 25.166 \\
\hline
\end{tabular}

\section{References}

[1] Abel, R.D., (1996). Water Pollution Biology. Taylor and Frances Publishers, Washington DC, p. 5.

[2] Alao, O., Arojojoye, O., Ogunlaja, O., Famuyiwa, A., (2010). Impact assessment of Brewery Effluent on Water Quality in Majawe, Ibadan, South Western Nigeria Researcher, 2 (5), 2128.

[3] APHA, (1992). Methods for the examination of water and wastewater, American Public Health Association, $5^{\text {th }}$ Edition, U.S.A., pp. 230-241.

[4] Chindah, A.C., Braide, A.S., Sibeudu, O.C., (2004). Distribution of hydrocarbons and heavy metals in sediment and a crustacean (shrimpls-penacus notialis) from the Bonny new Calabar River Estuary, Niger Delta. Ajeam-Ragee, 9, 114.

[5] Chukwu, O.J., (2008) Impact of food processing Effluents on the receiving streams, Environmental Journal 2, 5, 222-225.

[6] David, T.P., (2002). An introduction to practical biochemistry, $2^{\text {nd }}$ edition, McGraw Hill book company, U.K.,pp. 12-18.
[7] Emongor, V., Kealotswe, E., Koorapetse, L., Sankwasa, S., Keikanetswe, S., (2005). Pollution Indicators in Gaberone effluents. J. Appl. Sci. 5, 147-150.

[8] Fakayode, S.O., (2005). Impact of Industrial Effluents on water quality of the receiving Alaro River in Ibadan, Nigeria. Ajeam-Ragee, 10, 1-13.

[9] FMENV, (1991). Guidelines and standards for Environmental Pollution Control in Nigeria. Federal Environmental Agency (FEDA), Lagos.

[10] Futado, A.A., Albuquerque, R.T., Leite, S.R., Pecamba, R.P., (1998). Effect of Hydraulic retention time on Nitrification in an airlift biological reactor. Brazilian Journal of Chemical Engineering, 15, 1-7.

[11] Olayinka, K.O., (2004). Studies on industrial pollution in Nigeria: The effects of Textile Effluents on the quality of ground water in some parts of Lagos. Nigerian Journal of Health and Biomedical Sciences, 3, 44-50.

[12] Ugochukwu, N.C., (2004). Effluent monitoring of an oil servicing company and its impact on the environment, AjeamRagee, 8, 27-30. 